\title{
A presença da memória na arte contemporânea e seus desdobramentos
}

\section{La presencia de la memoria en el arte contemporáneo y sus desarrollos}

\author{
${ }^{1}$ Gabriela Zilli \\ 1gbazilli@gmail.com, Universidade Federal de Pelotas.
}

\begin{abstract}
Resumo
Este trabalho representa um recorte da pesquisa que vem sendo desenvolvida no mestrado do programa de pósgraduação em Memória Social e Patrimônio Cultural/ UFPel, com foco na área de conservação de arte contemporânea. Objetiva fundamentar o entendimento da obra de arte como patrimônio comum, de importância não apenas histórica e artística, mas como um bem cultural de grande relevância social, e portanto de interesse do ponto de vista da área da conservação do patrimônio. A reflexão a seguir parte da relação entre arte e memória, tomando como base as perspectivas de historiadores da arte e estudiosos da memória social. Através da revisão bibliográfico desenvolvida na primeira fase da pesquisa, são discutidos os conceitos de arte e memória na contemporaneidade, suas correlações, suas construções sociais e as demais relações estabelecidas entre os diversos atores envolvidos nesses processos.
\end{abstract}

Palavras-chave: arte, memória, memória da arte.

\section{Introdução}

O entendimento da obra de arte em seu caráter contemporâneo, como bem cultural como patrimônio de uma comunidade, de uma região, de uma nação, ou da humanidade -, nos remete a relevantes questões sobre sua fruição e permanência no decorrer do tempo. A variação do sentido da palavra "arte"ao longo da história, tornou seu conceito algo difuso, podendo significar coisas diversas em tempos e lugares diferentes (Gombrich, 2012. p. 15). Desde a pré-história observada nas pinturas rupestres até a contemporaneidade, expressa em grandes instalações e espetáculos urbanos, a arte mantém a característica comunicativa de linguagem. Pode-se dizer, dessa forma, que ela é produto da cultura de cada povo, dos seus princípios, crenças e valores. Partindo dessa premissa percebe-se, na produção artística e sua apreciação, a presença da memória como prática de intermediação entre as relações socioculturais. A arte torna-se espaço de rememoração e elaboração de memórias.

A memória é vista aqui não apenas como lembranças de fatos passados, estanques na história, mas como uma produção do presente. Em sua forma individual corresponde ao conjunto de funções psíquicas que permitem ao indivíduo conservar certas informações e atualizar impressões ou informações passadas, ou que ele representa como passadas (LE GOFF, 1990. p. 423). Nas palavras de Joel Candau "uma reconstrução continuamente atualizada do passado" (CANDAU, 2014. p. 9).

A consolidação da produção artística como uma atividade cultural ${ }^{1}$ e a ruptura com as formas tradicionais de arte a partir do século XX, posteriormente aliada à sua

1 A atividade cultural é vista aqui como um potencial transformador que almeja, através da capacidade criativa, a preservação das identidades que caracterizam as sociedades e os grupos sociais. Além disso, segundo a UNESCO, "toda criação tem suas origens nas tradições culturais, (...) essa é a razão pela qual o patrimônio, em todas suas formas, deve ser preservado, valorizado e transmitido às gerações futuras." (Declaração Universal sobre a Diversidade Cultural, 2002 CLT.2002/WS/9) 
desmaterialização em direção à uma arte efêmera e experimental, torna a memória elemento imprescindível para a existência da obra enquanto tal. A arte se enquadra e compartilha das expressões da memória, possuindo importante papel social. Desta forma, ambas encontram-se intrinsecamente ligadas. A memória servindo de subsídio e ferramenta necessária ao fazer artístico, a arte servindo de suporte perpetuador da memória.

\section{Objetivos}

As reflexões desenvolvidas neste trabalho objetivam buscar fundamentações para o entendimento da obra de arte como bem cultural, de importância social através de sua relação com as práticas memoriais. A discussão faz parte dos objetivos de uma pesquisa maior, que vem sendo desenvolvida para o mestrado do programa de Pós-Graduação em Memória Social e Patrimônio Cultural da UFPel, com foco na área de conservação de arte contemporânea. A compreensão destes conceitos é fundamentais para determinar a relevância da conservação (ou manutenção) das obras de criação contemporânea, levando em consideração sua natureza (muitas vezes efêmera, e até mesmo imaterial) e o seu papel ocupado na sociedade como patrimônio. Além disso, o trabalho visa trazer a luz desta pesquisa e das que ainda serão desenvolvidas, uma análise que possa contribuir na compreensão da importância das manifestações destas práticas na sociedade atual.

\section{A relação entre arte e memória}

A memória enquanto formadora da identidade social do indivíduo se revela nos mais diversos tipos de expressões culturais: desde sua forma imaterial como festas populares, ritos religiosos e tradições passadas oralmente, até suas manifestações mais concretas como as expressões da linguagem escrita e a produção dos inúmeros objetos que transmitem algo do passado e da cultura de uma sociedade. Dentre essas inúmeras formas de expressão, destacase a produção artística.

Como matéria na concepção de uma obra de arte, a memória passa pelo sistema de musealização, onde seu valor é atribuído tanto pela sua característica retentora de informações simbólicas quanto pelo seu potencial histórico. Assim sendo, pode-se encontrar nestes objetos uma memória por eles representada, simbólica e objetivada pelo artista (a exemplo das pinturas clássicas de narrativas e fatos históricos, como as obras do pintor brasileiro Victor Meirelles, 1832-1903); e outra memória vinculada à sua própria existência histórica, relativa à obra enquanto objeto material (pode-se citar como exemplo a Mona Lisa de Leonardo Da Vinci, ou ainda $O$ Grito de Edvard Munch como munidas de uma memória representativa de um determinado período histórico, de um artista renomado e/ou de um estilo específico de arte).

Do mesmo modo, a obra de arte em sua característica de objeto museológico torna-se suporte perpetuador de lembranças e motivador de memórias. Tanto em sua forma física, quanto em sua forma imaterial - representada apenas nos registros, projetos, instruções e proposições -, a obra de arte é capaz de proporcionar a construção de novas memórias através das suas representações. Em seu caráter simbólico, ao mesmo tempo em que resgata lembranças do espectador, a arte proporciona elementos capazes de construir memórias independentemente do sujeito ter vivenciado ou não a experiencia retratada pelo artista.

$\mathrm{Na}$ arte contemporânea, principalmente, a dimensão simbólica se evidencia sobre a dimensão material. As proposições artísticas, happenings e performances, aliados à obras constituídas de materiais de durabilidade duvidosa ou propositalmente efêmeros, originam uma memória mais volátil se analisada pelo viés da pouca ou nula durabilidade do suporte de comunicação. A memória da arte restringe-se dessa maneira à memória e percepção individual do espectador - ou colaborador da ação - e à cristalização em registros históricos 
como fotografias e vídeos. Porém deve-se ressaltar que essa mesma memória, por outro viés, é o que permite a compreensão da arte como uma construção mental, e não apenas um procedimento técnico (ARGAN, 2013. p. 360). É essa memória o que dá legitimidade ao uso, na produção artística, de objetos efêmeros, perecíveis, produtos industriais, sem causar estranhamento. Ninguém, hoje em dia, questiona o valor histórico e artístico de A Fonte de Marcel Duchamp.

\section{Conclusões}

A memória de uma obra de arte não encontra-se meramente inerente ao objeto material, como memória do artista a ser transmitida; assim como o objeto artístico não possui sua existência apenas fundamentada em seu caráter memorável. Dessa forma, apesar da correlação entre essas práticas, o objeto artístico somente adquire sentido em sua interação com o espectador, tanto em sua característica de transmissor de uma mensagem quanto em seu caráter e função social.

Através da análise das possíveis manifestações da memória observou-se que esta apresenta-se, desde seu conceito mais simples, com um certo grau de ambiguidade. Enquanto é relativamente fácil defini-la de forma sintética como uma construção no presente de impressões do passado, torna-se complicado relacionar e aplicar esse conceito à arte. A pluralidade de expressões através das quais a arte se manifesta dificulta a definição de um conceito único para memória. Dessa forma, foi abordada a memória da arte enquanto objeto museológico, em seu caráter físico e imaterial, simbólico e histórico, porém isso não desqualifica outras formas que possam existir de se pensar essa relação.

\section{Referências}

ARGAN. Giulio Carlo. Arte Moderna. São Paulo: Companhia das Letras, 1992. 711 p.

ASSMANN, Aleida. Espaços da recordação. São Paulo, Editora da Unicamp, 2011, p. 317366

CANDAU, Joel. Memória e Identidade. São Paulo: Contexto, 2014

GOMBRICH, E. H. História da Arte. Rio de Janeiro. Ed. LTC, 2012

HALBWACHS, Maurice. A memória coletiva. Rio de Janeiro, Vertice, 1990

HEIDEN, Roberto. O Museu como Lugar para a Memória da Arte Contemporânea. Dissertação de Mestrado. Programa de Pós-Graduação em Memória Social e Patrimônio Cultural. UFPel. Pelotas, 2008

LE GOFF, Jacques. História e Memória. Campinas, Edunicamp, 1990

RICOEUR, Paul. A Memória, a História e o Esquecimento. Campinas, Edunicamp, 2007 